\title{
Wpływ dodatku melaminy i krzemionki w dogarbowaniu skór na palność i wybrane właściwości skór naturalnych
}

\author{
The Influence of the Addition of Melamine and Silica in the Retanning of Leather \\ on the Flammability and other Selected Properties of Leather
Влияние добавления меламина и диоксида кремния на воспламеняемость и другие выбранные свойства кожи при додубливании кожи

\begin{abstract}
ABSTRAKT
Cel: Określenie wpływu dodatku melaminy i krzemionki w procesie dogarbowania na wybrane właściwości skór ze szczególnym uwzględnieniem palności. Artykuł przedstawia wyniki prac związanych z obróbką skór na etapie dogarbowania. W dogarbowaniu zastosowano różne ilości krzemionki i melaminy w celu uzyskania wyższej odporności skór na palność.

Metody: W pracy wykonano badania eksperymentalne, które obejmowały dogarbowanie skór naturalnych oraz badania wybranych właściwości skór otrzymanych w wyniku tego procesu. Dogarbowanie wykonano w skali laboratoryjnej. Badania skór obejmowały parametry związane z komfortem użytkowania wyrobów skórzanych takich jak miękkość i przepuszczalność pary wodnej. W zakresie palności badania przeprowadzono za pomocą specjalnie opracowanych metod. Wykonano także badania odporności skór na palenie w warunkach ograniczonego dostępu tlenu. Ponadto określono odporność hydrotermiczną otrzymanych skór.

Wyniki: Skład kompozycji dogarbowującej i rezultaty badań właściwości skóry posłużyły za bazę do optymalizacji oraz określenia wpływu dodatków melaminy i krzemionki na badane właściwości skóry. Rezultaty badań właściwości dogarbowanych skór wskazują na istnienie zależności między ilością dodatków w dogarbowaniu a palnością skóry.

Wnioski: Na podstawie przeprowadzonych badań stwierdzono, że:

1. Wzrost ilości użytej melaminy i krzemionki w składzie kompozycji powoduje wzrost odporności próbek skóry na przepalenie, przy czym dominujący jest wpływ melaminy.

2. Dogarbowanie zarówno z dodatkami (krzemionka i melamina), jak i bez dodatków nieznacznie tylko obniża przepuszczalność pary wodnej dla wszystkich badanych wariantów. Dogarbowanie prowadzi do wzrostu temperatury skurczu o max. $4^{\circ} \mathrm{C}$.

3. Wyniki optymalizacji wskazują, że kompromisowe optimum przy założonych właściwościach skóry utrzymuje się przy dodatku melaminy i krzemionki w kompozycji dogarbowującej na poziomie 0,06-0,5\% dla krzemionki i 0,35-0,65\% dla melaminy w warunkach przeprowadzonych badań.

Słowa kluczowe: skóra naturalna, palność, melamina, krzemionka, dogarbowanie, optymalizacja

Typ artykułu: oryignalny artykuł naukowy
\end{abstract}

Przyjęty: 31.08.2018; Zrecenzowany: 09.11.2018; Zatwierdzony: 22.11.2018;

Identyfikatory ORCID autorów: K. Śmiechowski - 0000-0002-8207-717X; M. Stachowicz - 0000-0002-8800-7682;

Procentowy wkład merytoryczny: K. Śmiechowski - 90\%; M. Stachowicz - 10\%;

Proszę cytować: BiTP Vol. 51 Issue 3, 2018, pp. 68-84, doi: 10.12845/bitp.51.3.2018.5;

Artykuł udostępniany na licencji CC BY-SA 4.0 (https://creativecommons.org/licenses/by-sa/4.0/)

\begin{abstract}
Aim: The purpose of the research was to determine the effect of the addition of melamine and silica in the retanning process on selected properties of leather with particular regard to flammability. The article presents the results of work related to the processing of leather at the retanning stage. Various amounts of silica and melamine were used in retanning in order to achieve a higher resistance of leather to flammability.

Methods: The work involved experimental tests, which included retanning of natural leather and testing of selected properties of the leathers obtained Retanning was carried out on a laboratory scale. The leather testing included parameters related to the comfort of using leather goods such as softness
\end{abstract}


and water vapor permeability. Flammability tests of leather were carried out using specifically developed methods. The tests of flame resistance of leather under conditions of limited access of oxygen were also carried out. In addition, the hydrothermal resistance of the resulting hides was determined. Results: The composition of a retanning mixture and the results of the leather properties tests were the basis for the optimisation and determination of the effect of melamine and silica on the examined properties of leather. The results of investigations of the properties of retanned leather show a correlation between the amount of additives in retanning and on the flammability of the leather.

Conclusions: Based on the conducted tests, it was found that:

1. The increase in the amount of melamine and silica used in the composition of the mixture increases the resistance of leather samples to burning through (with the influence of melamine being the more important of the two)

2. Retanning both with additives (silica and melamine) and without additives only slightly reduces the water vapour permeability for all tested variants. Retanning leads to an increase in the shrinkage temperature by max. $4^{\circ} \mathrm{C}$.

3. The results of the optimisation show that the compromise optimum with the assumed properties of the leather is obtained with the addition of melamine and silica in the retanning mixture at $0.06-0.5 \%$ for silica and $0.35-0.65 \%$ for melamine under the test conditions.

Keywords: natural leather, flammability, melamine, silica, retanning, optimisation

Type of article: original scientific article

Received: 31.08.2018; Reviewed: 09.11.2018; Accepted: 22.11.2018;

Authors' ORCID IDs: K. Śmiechowski - 0000-0002-8207-717X; M. Stachowicz - 0000-0002-8800-7682;

Percentage contribution: K. Śmiechowski - 90\%; M. Stachowicz - 10\%;

Please cite as: BiTP Vol. 51 Issue 3, 2018, pp. 68-84, doi: 10.12845/bitp.51.3.2018.5;

This is an open access article under the CC BY-SA 4.0 license (https://creativecommons.org/licenses/by-sa/4.0/).

\section{АННОТАЦИЯ}

Цель: Определение влияния добавления меламина и диоксида кремния в процессе додубливания на отдельные свойства кожи с особым вниманием к свойству воспламеняемости. В статье представлены результаты работ, связанных с обработкой кожи на стадии додубливания. При додубливании, с целью получения более высокой огнеустойчивости были использованы различные количества диоксида кремния и меламина.

Методы: В работе были проведены экспериментальные испытания, которые включали додубливание натуральной кожи и тестирование выбранных свойств кожи, полученных в результате этого процесса. Додубливание проводилось в лабораторных условиях. Тестирование кожи включало параметры, связанные с удобством использования изделий из кожи, такие как мягкость и проницаемость для водяного пара. С точки зрения воспламеняемости, испытания проводились с использованием специально разработанных методов, а также проводились испытания на стойкость кожи к горению в условиях ограниченного доступа кислорода. Кроме того, была определена гидротермическая стойкость полученной кожи.

Результаты: Состав додубливающей композиции и результаты испытаний свойств кожи послужили основой для оптимизации и определения влияния добавок меламина и диоксида кремния на исследуемые свойства кожи. Результаты исследований свойств додубленной кожи свидетельствуют о наличии зависимости между количеством добавок при додубливании и воспламеняемостью кожи.

Выводы: на основании проведенных испытаний было установлено, что:

1. Увеличение количества меламина и диоксида кремния, используемых в композиции, повышает огнестойкость образцов кожи, причем влияние меламина является доминирующим.

2. Додубливание как с добавками (диоксид кремния и меламин), так и без добавок немного снижает проницаемость водяного пара для всех испытанных вариантов. Додубливание приводит к увеличению температуры усадки на макс. $4^{\circ} \mathrm{C}$

3. Результаты оптимизации показывают, что компромиссное оптимальное количество добавления меламина и диоксида кремния при додубливании с целью получения предполагаемых свойств кожи составляет 0,06-0,5\% для диоксида кремния и 0,35-0,65\% для меламина в лабораторных условиях.

Ключевые слова: натуральная кожа, воспламеняемость, меланин, диоксид кремния, додубливание, оптимизация

Тип статьи: оригинальная научная статья

Принята: 31.08.2018; Рецензирована: 09.11.2018; Одобрена: 22.11.2018;

Идентификаторы ORCID авторов: K. Śmiechowski - 0000-0002-8207-717X; M. Stachowicz - 0000-0002-8800-7682;

Процентоне соотношение участия в подготовке статьи: К. Śmiechowski - 90\%; M. Stachowicz - 10\%;

Просим ссылаться на статью следующим образом: BiTP Vol. 51 Issue 3, 2018, pp. 68-84, doi: 10.12845/bitp.51.3.2018.5;

Настоящая статья находится в открытом доступе и распространяется в соответствии с лицензией CC BY-SA 4.0 (https://creativecommons.org/ licenses/by-sa/4.0/).

\section{Wprowadzenie}

W ostatnim stuleciu obserwuje się bardzo duży wzrost produkcji i zastosowań materiałów na bazie polimerów syntetycznych, które zwykle charakteryzują się niską odpornością na palenie. Ponieważ w powietrzu atmosferycznym, będącym środowiskiem eksploatacji materiałów inżynierskich, znajduje się ponad $20 \%$ tlenu, problemy zwiększenia odporności tych

\section{Introduction}

The last century has seen a sharp increase in the production and use of materials based on synthetic polymers, which are usually characterised by a low flame resistance. Since oxygen makes up $20 \%$ of the atmospheric air, which is the environment in which engineering materials are used, the problems of increasing the flame resistance of these materials are extremely 
materiałów na palenie mają niezwykle istotne znaczenie. Rozwój cywilizacyjny wiąże się między innymi z rosnącą liczbą wysokich budynków, które skupiają na małej powierzchni ziemi dużą liczbę ludzi (wysokie budynki mieszkalne, biura, hotele). W przypadku pożaru stanowią one olbrzymie zagrożenie dla przebywających w nich osób. To z kolei powoduje wzrost zainteresowania badaniami w zakresie palności zastosowanych materiałów.

Ze skóry naturalnej wykonuje się wiele wyrobów powszechnego użytku, takich jak obuwie, galanteria, tapicerka meblowa lub samochodowa. Badania skór naturalnych polegają na określeniu wpływu różnych operacji wyprawy i zastosowanych środków na właściwości tych materiałów, w tym odporności na palenie.

W literaturze przedmiotu można znaleźć wiele pozycji poświęconych badaniom skór. Przedmiotem jednej z nich była m.in. analiza wpływu poszczególnych operacji obróbki (np. garbowania, natłuszczania) oraz stosowanych w niej dodatków. Oceniano również wpływ zastosowanych garbników, środków natłuszczających, dogarbowujących oraz zmniejszających palność. Okazuje się, że skóra wyprawiona posiada naturalną, wysoką odporność na ogień. Jednakże rodzaj skóry, rodzaj garbnika, środka dogarbowującego i środka natłuszczającego wpływają nie tylko na palność skóry, ale także na sposób palenia [1].

W innych badaniach [2] analizowano również wpływ garbowania, w tym zastosowania różnych garbników (chromowego, na bazie aldehydu glutarowego i garbników roślinnych) na palność skór. Ponadto znaleziono zależność pomiędzy gęstością skór a palnością. Stwierdzono, że największą odporność na palenie miały skóry garbowania roślinnego, które charakteryzowały się także największą gęstością. Na kolejnej pozycji znalazły się skóry garbowania chromowego, a następnie skóry garbowane garbnikiem aldehydowym. Ranking palności jest taki sam, jak w sekwencji gęstości [2]. Przedmiotem badań był również wpływ zastosowania różnej powłoki wykończalniczej na skórę. Użyto różnych materiałów błonotwórczych na bazie poliuretanu, poliakrylanu, nitrocelulozy i białka. Stwierdzono jednoznacznie, że wprowadzenie do materiału błonotwórczego pigmentu zdecydowanie podwyższa odporność na palność, jednocześnie większa ilość powłoki wykończalniczej to mniejsza odporność na palenie [3].

Ważnym, niezbędnym procesem obróbki skór jest natłuszczanie. Obecnie stosowana najczęściej technologia natłuszczania skór bazuje na wykorzystaniu metody emulsyjnej. Zdolność tworzenia emulsji wodnej tłuszczów uzyskuje się między innymi poprzez siarczanowanie i siarczynowanie. Użycie olejów siarczanowanych daje widoczny lepszy efekt podwyższenia odporności skór na palenie w porównaniu do olejów siarczynowanych [4].

Zastosowanie do skór różnych środków opóźniających palenie było przedmiotem badań w kolejnej publikacji. Wprowadzone środki na bazie związków amonowych, związków boru, fosforu, melaminy i żywicy aminowej pozwalają otrzymać skóry o zwiększonej odporności na palenie. Zmienia się charakterystyka organoleptyczna, jednocześnie występuje redukcja wytrzymałości skóry [5].

Wzrost odporności skór na palność obserwowano przy zastosowaniu do wykończenia tych skór nanokompozytu. Nanokompozyt otrzymano na bazie modyfikowanego montmorylonitu z wodną dyspersją poliuretanu. Zastosowanie $4 \%$ nanokompozytu powoduje wzrost odporności skór na palenie oznaczany important. The development of civilisation is connected, among other things, with the growing number of high-rise buildings, which concentrate a large number of people (tall residential buildings, offices, hotels) in a small area. In the event of a fire, they constitute a tremendous threat to the persons within. This in turn results in studies on the flammability of materials becoming increasingly interesting.

Many everyday products, such as shoes, accessories, furniture or car upholstery are made of natural leather. Studies on natural leather aim at determining the influence of various dressing techniques and agents on the properties of this material, including flame resistance.

In the literature on the subject there are many publications on leather studies. One of these studies concerned, among other things, the impact analysis of individual processing operations (e.g. tanning and fatliquoring), and the additives used. The influence of the applied tanning agents, fatliquors, retanning agents and flame retardants was also evaluated. It appears that dressed leather has natural, high flame resistance. On the other hand, the types of the tanning and retanning agents, and fatliquors influence not only the flammability of leather, but also the manner of its combustion [1].

Other studies [2] analysed the impact of tanning, including the used tanning agents (based on chromium, glutaraldehyde and vegetable substances) on the flammability of leather. Furthermore a relation between leather density and flammability has been established. It was determined that vegetable-tanned leather, which are characterised by highest density, were most flame-resistant. Less flame resistant was chrome tanned leath$\mathrm{er}$, and the least resistant was glutaraldehyde leather. The flame resistance ranking followed the sequence of density [2]. The use of various finishing coats was also evaluated. Various film-forming materials based on polyurethane, polyacrylate, nitrocellulose and protein were analysed. It was clearly determined that the introduction of a pigment into the film-forming material significantly increases flame resistance, while, at the same time, a greater amount of the finishing coat results in lower flame resistance [3].

Oiling is essential in leather processing. Nowadays, the most commonly used method uses emulsions. The ability to create emulsions of fats in water is facilitated by sulphating and sulphiting. The use of sulphated oils results in a markedly better effect when compared with sulphited oils in terms of improving the flame resistance of leather [4].

The application of various flame retardants to leather was the subject of research in another publication. The introduction of agents based on ammonium compounds, boron compounds, phosphorus compounds, melamine and amine resin makes it possible to obtain leather with increased flame resistance. The organoleptic characteristics change and the durability of leather decreases [5].

An increase in the flame resistance of leather was observed when a nanocomposite was applied in the finishing process. The nanocomposite was obtained on the basis of modified montmorillonite with water-borne polyurethane dispersion. The application of $4 \%$ nanocomposite results in an increase in flame resistance determined using the limiting oxygen index, 
za pomocą indeksu tlenowego o 3,6 jednostki [6]. Inne badania również wykazują, że nanokompozyt opóźniający palenie i montmorylonit zmodyfikowany bromkiem cetylotrimetyloamoniowym powodują wzrost ognioodporności skóry [7]. Zastosowanie nanokompozytu na bazie żywicy aminowej między innymi z melaminą pozwoliło na otrzymanie trudnopalnego pyłu. Obecność tego pyłu podwyższa odporność na palność włókien kolagenowych o ponad 11 jednostek indeksu tlenowego [8]. Wprowadzenie do skóry trudnopalnego środka wykończającego, zawierającego fosfor i azot (Pyrovatex CP) z jednoczesną obecnością modyfikowanej melaminy wpływa pozytywnie na ognioodporność skór[9].

Poprawa odporności na palność została uzyskana także przez wprowadzenie do skóry trudnopalnej żywicy na bazie żywicy aminowej, siarczanu tetrahydroksymetylofosfoniowego (tetra-hydroxymethyl phosphonium sulfate) i modyfikowanego montmorylonitu [10].

Obróbka skór z dodatkami w postaci nanocząstek krzemionki i nanocząsteczek dwutlenku tytanu podwyższa odporność skór na testy cieplne, ogniowe, a także odporność na grzyby. Testy wykazały lepsze wskaźniki zachowania się podczas spalania i jako przewodnik ciepła [11].

W wielu przypadkach do podwyższenia ognioodporności włókien (w tym białkowych, takich jak kolagen) służą związki organofosforowe, trimetylomelamina oraz związki kompleksowe tytanu lub cyrkonu $[12,13]$.

Warto podkreślić, że ekspansja materiałów "skórzanych" na bazie polimerów syntetycznych niesie ze sobą poważne zagrożenia dotyczące odporności na palenie oraz toksyczność dymu. Skóry na bazie kolagenu (skóry surowej, która jest surowcem odnawialnym) w porównaniu do skór syntetycznych wykazują w wyżej wymienionym zakresie właściwości zdecydowaną przewagę [14]. Istotnym parametrem użytkowym skóry, związanym z komfortem, jest jej miękkość, a także przepuszczalność pary wodnej. W wielu badaniach wprowadzenie dodatków podwyższających odporność skór na palność następuje w procesach wykończenia kąpielowego, w tym natłuszczania i dogarbowania. Sposób natłuszczania i dogarbowania oraz parametry tych procesów i ich wpływ na miękkość były przedmiotem wielu badań $[15,16]$.

Zastosowanie nowoczesnych organiczno-nieorganicznych cząstek hybrydowych fosforu i krzemionki (SiO2 @ DPP) zsyntetyzowanych poprzez reakcję hydrotermalną do polepszenia ognioodporności poliwęglanu (PC) było przedmiotem badań naukowców z Chin. Pomiar wielkości indeksu tlenowego zmodyfikowanego poliwęglanu pokazał poziom wynoszący (LOI) 29,3\%. Skuteczne zmniejszenie palności PC nastąpiło już przy zastosowaniu minimalnej ilości SiO2 @ DPP wynoszącej tylko 0,8\% wag [17].

Okazuje się, że wprowadzenie w procesie dogarbowania montmorylonitu sodowego $(\mathrm{Na}+\mathrm{Mt})$ do skóry wet-blue nie tylko może podwyższyć stabilność skóry w azocie i powietrzu (ocenianą wg termograwimetrii). Analiza morfologiczna za pomocą skaningowej mikroskopii elektronowej wykazuje, że cząsteczki Na + Mt są równomiernie rozprowadzone i drobno rozproszone w strukturze skóry. Udowodniono także, że zastosowanie 1 i $3 \%$ środka $\mathrm{Na}+\mathrm{Mt}$ (wagowo) wpływa pozytywnie na właściwości mechaniczne (mianowicie wytrzymałość na rozciąganie i rozdarcie) [18].

Badania literaturowe potwierdzają, że skóra naturalna (zawierająca głównie polimer naturalny - kolagen) ma znacznie by 3.6 [6]. Other studies also show that a flame-retardant nanocomposite and cetyltrimethylammonium-bromide-modified montmorillonite improve the flame resistance of leather [7]. The application of a nanocomposite based on amine resin with, i.a., melamine, facilitated the production of flame-retarding dust. The presence of this dust increased the flame resistance of collagen fibres expressed using the limiting oxygen index by more than 11 [8]. The introduction of a flame-retarding finishing agent containing phosphorus and nitrogen (Pyrovatex $\mathrm{CP}$ ) into leather, coupled with the presence of modified melamine, has a positive impact on the flame resistance of leather [9].

Flame resistance was also increased through the introduction of flame-retarding resin based on amine resin, tetra-hydroxymethyl phosphonium sulfate and modified montmorilIonite [10].

The processing of leather with added silica or titanium dioxide nanoparticles improves leather resistance in heat and flame tests and resistance to fungi. The test demonstrated significantly better behaviour during combustion and as a heat conductor [11].

In many cases organophosphorus compounds, trimethylmelamine and complex compounds of titanium or zirconium are used to improve the flame resistance of fibres (including protein fibres such as collagen) $[12,13]$.

It is worth highlighting that the expansion of "leather" materials based on synthetic polymers poses serious risks in terms of flame resistance and smoke toxicity. In this context, collagen-based leather (raw leather which is a renewable resource) has much better properties than synthetic leather [14]. Softness, associated with comfort, as well as water vapour permeability are important performance parameters of leather. In many studies agents which improve the flame resistance of leather are introduced as part of bathing, including oiling and retanning. The method of oiling and retanning, as well as the parameters of these processes and their influence on softness were the subjects of many studies $[15,16]$.

The application of novel organic-inorganic hybrid particles of phosphorus and silica (SiO2 @ DPP) synthesised through a hydrothermal reaction to improve the fire retardance of polycarbonate $(\mathrm{PC})$ was the subject of research of Chinese scientists. The measurement of oxygen index values of modified polycarbonate demonstrated a LOI of $29.3 \%$. An effective decrease in PC flammability was obtained with a minimum quantity of SiO2 @ DPP amounting to $0.8 \mathrm{wt} \%$ [17].

It appears that the introduction of sodium montmorillonite $(\mathrm{Na}+\mathrm{Mt})$ to wet-blue leather can have other effects than only improving leather stability in nitrogen and air (evaluated by means of thermogravimetric analysis). The analysis of morphology using a scanning electron microscope demonstrated that $\mathrm{Na}+$ Mt molecules were uniformly distributed and finely scattered in the leather structure. It was proven also that the application of 1 and $3 \mathrm{wt} \%$ of $\mathrm{Na}+\mathrm{Mt}$ has a positive impact on mechanical properties (tensile and tear strength) [18].

The analysis of the literature confirms that natural leather (containing mainly collagen - a natural polymer) has a much higher flame resistance than the commonly used 
wyższą odporność na palenie niż zwykle stosowane zamienniki skóry (polimery syntetyczne). Wspomniany dodatek powinien więc być przedmiotem badań mających na celu uzyskanie jeszcze wyższej odporności na palenie przy zachowaniu innych istotnych parametrów użytkowych. Należy przypuszczać, iż zastosowanie w kompozycji dogarbowującej mieszanki krzemionki i melaminy pozwoli osiągnąć taki skutek. W literaturze brak jest badań sprawdzających synergiczny efekt zastosowań obydwu dodatków do zagarbowania skóry. W pracy zastosowano specjalne metody oznaczania palności, które zdecydowanie bardziej odzwierciedlają rzeczywiste warunki związane z procesem palenia konkretnych wyrobów skórzanych (obuwia lub odzieży) podczas ich eksploatacji.

Celem niniejszego artykułu było określenie wpływu wybranych operacji wykończania kąpielowego na określone właściwości skór kolagenowych. Szczególnym przedmiotem zainteresowania było dogarbowanie i właściwości skór w zakresie palności. Zastosowano program do optymalizacji pozwalający na wybór kompromisowego optimum parametrów skóry na podstawie wyników badań specjalnie zaplanowanych doświadczeń technologicznych.

W pracy wykonano badania eksperymentalne, które obejmowały:

- dobór kompozycji dogarbowującej na bazie żywicy akrylowej z dodatkiem krzemionki i melaminy (na podstawie badań stabilności polidyspersji wodnych kompozycji natłuszczających)

- dogarbowanie skór

- badanie palności otrzymanych skór.

Na podstawie składu kompozycji dogarbowującej oraz wyników badań właściwości otrzymanych skór przeprowadzono optymalizację udziału dodatków w kompozycji dogarbowującej skóry.

\section{Część doświadczalna Surowce i chemikalia}

W pracy użyto półfabrykatu skórzanego w postaci połówek skór bydlęcych w stanie wet-blue. Ponadto w obróbce zagarbowanego kolagenu zastosowano: żywicę akrylową Rokryl GA16, metylocelulozę, melaminę, krzemionkę koloidalną HDK N20 (IMCD), emulgator (SILASTOL E7-prod.Schill\&Seilacher).

W tabeli 1 przedstawiono właściwości żywicy akrylowej Rokryl GA16.

Tabela 1. Właściwości żywicy Rokryl GA16 [19]

Table 1. Presents the properties of Rokryl GA16 acrylic resin skin substitutes (synthetic polymers). The additive in question should therefore be tested in order to obtain even higher flame resistance while maintaining other relevant performance parameters. One may assume that the use of a mix of silica and melamine in the retanning mixture will make it possible to achieve such an effect. The available literature lacks studies evaluating the synergistic effect of both these tanning agents. This work consisted of special methods of determining flammability, which much more reliably reflect the real conditions of combustion of specific leather products (footwear or clothes) during their use.

The goal of the work was to determine the impact of the selected bath finishing operations on the specific properties of collagen leather. Retanning and leather properties in terms of flammability constituted the special object of focus. An optimisation program was used which allowed the selection of a compromise optimum of leather parameters based on the results of the analyses of specially planned engineering tests.

The work involved experiments including:

- the selection of an acrylic-resin-based retanning mixture with added silica and melamine (on the basis of studies of the stability of molecular-weight distribution of water-based fatliquor mixtures).

- leather retanning

- flammability testing of the obtained leather.

On the basis of the composition of the retanning mixture and the results of the property analysis of the obtained skins, the proportion of additives in the retanning mixture was optimised

\section{The experimental part}

\section{Raw materials and chemicals}

A leather semi-finished product, i.e. wet-blue half hides, was used for the purposes of this work. The following were used in the processing of tanned collagen: Rokryl GA16 acrylic resin, methyl cellulose, melamine, colloidal silica HDK N20 (IMCD), and an emulsifier (SILASTOL E7 by Schill\&Seilacher).

Table 1 presents the properties of Rokryl GA16 acrylic resin.
Właściwość fizykochemiczna/Physico-chemical property

Wygląd/Appearance
Wartość/Value

lepka, klarowna ciecz o barwie od jasnożółtej do jasnobrązowej/ viscous, clear liquid, light yellow to pale brown

\begin{tabular}{cc}
\hline Ładunek/Charge & anionowy/anionic \\
\hline Substancja aktywna, $\%[\mathrm{~m} / \mathrm{m}] /$ Active substance, $\%[\mathrm{~m} / \mathrm{m}]$ & $38-42$ \\
\hline $\mathrm{pH}$ produktu handlowego/pH & $6,0-7,5$ \\
\hline Rozpuszczalność w wodzie/Water solubility & całkowita/total \\
\hline Gęstość w temp. $20^{\circ} \mathrm{C}, \mathrm{g} /$ Density at $20^{\circ} \mathrm{C}, \mathrm{g}$ & $1,13-1,16$ \\
\hline Lepkość w temp. $20^{\circ} \mathrm{C}, \mathrm{mPa} \cdot \mathrm{s} /$ Viscosity at $20^{\circ} \mathrm{C}, \mathrm{mPa} \cdot \mathrm{s}$ & max. 3500 \\
\hline
\end{tabular}


Tabela 2. Charakterystyka melaminy [20]

Table 2. Characteristics of melamine [20]

\begin{tabular}{cc}
\hline Właściwość/ Physico-chemical property & Wartość/Value \\
\hline Zawartość melaminy, [\%]/The content of melamine, [\%], & 99,8 \\
\hline Zawartość popiołu, [\%]/The content of ash [\%] & 0,02 \\
\hline Zawartość wilgoci, [\%]/Moisture content, [\%] & 0,1 \\
\hline Reaktywność [min]/Reactivity [min] & 40 \\
\hline Barwa żywicy melaminowo-formaldehydowej, [ํt-Co]/Color of melamine-formaldehyde resin, [Pt-Co] & 20 \\
\hline Zawartość żelaza, [ppm]/ The content of Iron, [ppm] & 1 \\
\hline
\end{tabular}

W tabeli 3 przedstawiono właściwości krzemionki koloidalnej HDK N20 (IMCD).

Tabela 3. Charakterystyka krzemionki koloidalnej HDK N20 (IMCD) [21]

Table 3. Characteristics of colloidal silica HDK N20 (IMCD) [21]

\begin{tabular}{cc}
\hline Właściwość/ Property & Wartość/Value \\
\hline Powierzchnia właściwa/ BET surface & $175-225 \mathrm{~m} 2 / \mathrm{g}$ \\
\hline Straty przy suszeniu/ Loss on drying & $<1,5 \%$ \\
\hline Pozostałość na sicie/ Sieve residue & $<0,03 \%$ \\
\hline Gęstość/ Tamped density & $40 \mathrm{~g} / \mathrm{l}$ \\
\hline $\mathrm{pH}(\mathrm{w}$ 4\% dyspersji wodnej)/ $\mathrm{pH}$ (in 4\% aqueous dispersion) & $3,8-4,3$ \\
\hline
\end{tabular}

W tabeli 4 przedstawiono właściwości metylocelulozy.

Table 4 presents the properties of methyl cellulose.
Table 3 presents the properties of colloidal silica HDK N20 (IMCD).

Tabela 4. Charakterystyka metylocelulozy [23]

Table 4. Characteristics of methyl cellulose [23]

\begin{tabular}{cc}
\hline Właściwość fizykochemiczna/ Physico-chemical property & Wartość/Value \\
\hline Wygląd/ Appearance & proszek o barwie od białej do żółtawej/ white to yellowish colour powder \\
\hline $\mathrm{pH}(10 \mathrm{~g} / \mathrm{l}) \mathrm{w} 20^{\circ} \mathrm{C} / \mathrm{pH}(10 \mathrm{~g} / \mathrm{l})$ in $20^{\circ} \mathrm{C}$ & $6-8$ \\
\hline Temperatura palenia się/ Burning temperature & $>360^{\circ} \mathrm{C}$ \\
\hline Temperatura rozkładu/ Decomposition temperature $>$ & $>200{ }^{\circ} \mathrm{C}$ \\
\hline Dolna granica niebezpieczeństwa wybuchu/ Lower limit of danger of explosion & $30 \mathrm{~g} /$ \\
\hline Gęstość w $20^{\circ} \mathrm{C} /$ Density at $20^{\circ} \mathrm{C}$ & $\mathrm{ca} .1,3 \mathrm{~g} /$ \\
\hline Rozpuszczalność w / mieszalność z wodą w $20^{\circ} \mathrm{C} /$ & $>10 \mathrm{~g} / \mathrm{l}$
\end{tabular}

\section{Metody badań}

Metoda asymetryczna dobierania próbek skór do badań

Kompozycje na bazie żywicy akrylowej wprowadzono do skór wet-blue (zagarbowanych chromowo) z wykorzystaniem metody asymetrycznego doboru próbek. Metoda ta stosowana jest ze względu na topografię skóry. W ten sposób zdecydowanie zminimalizowano wpływ topografii na wyniki badań właściwości skór. Postępuje się tak w przypadku badań laboratoryjnych przeprowadzanych na próbkach skór. Badania wykonano dla trzech próbek skór; np. w wariancie 1 użyto próbek wyciętych z części topograficznych skóry 1, 12 i 17. Na ryc. 1 przedstawiono schemat pobierania próbek skór do badań z połówki skóry bydlęcej. 


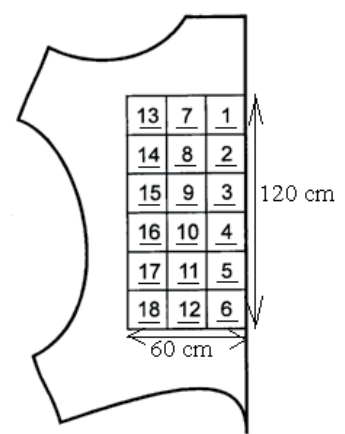

Rycina 1. Metoda pobierania próbek skór do badań

Figure 1. Method of leather sampling for testing

Źródło: Opracowanie własne.

Source: Own elaboration.

\section{Dogarbowanie skór wet-blue}

W sześciu szklanych cylindrycznych naczyniach (urządzenie typu Wacker) umieszczono odważone próbki skóry w kąpielach wodnych zawierających $10 \%$ różnych kompozycji. Zastosowano $100 \%$ wody w stosunku do masy skóry. Naczynia z zawartością obracano (czas -4 h, temperatura ok. $50^{\circ} \mathrm{C}$ ). Na 30 minut przed zakończeniem procesu do kąpieli dogarbowującej dodano roztwór kwasu mrówkowego (1\% czystego kwasu mrówkowego na masę skóry, stężenie kwasu 10\%). Następnie skóry zmiękczono mechanicznie (poprzez rozciąganie ) i wysuszono w odpowiednich warunkach do osiągnięcia wilgotności na poziomie 10-15\%. Stopień wprowadzenia dodatku melaminy i krzemionki do skóry oceniono w sposób pośredni poprzez oznaczenie suchej masy kąpieli przed i po dogarbowaniu (zostało ocenione na poziomie około $90 \%$ - dla wszystkich wariantów). Potwierdziła to także ocena organoleptyczna kąpieli wyczerpanych (po procesie).

\section{Oznaczenie temperatury skurczu}

Oznaczenie temperatury skurczu przeprowadzono wg PN-EN ISO 3380:2015-11 [24]. Wykonano 3 oznaczenia dla każdej próbki skóry, tzn. 9 prób dla każdego wariantu.

\section{Pomiar miękkości}

Pomiar miękkości wykonano wg PN-EN ISO 17235:2002 [25]. Przeprowadzono po 5 oznaczeń dla każdej próbki skóry, tzn. 15 prób dla każdego wariantu.

\section{Pomiar absorpcji (wchłaniania) kropli wody}

Przy pomocy pipety nanoszono kroplę wody destylowanej na badaną próbkę skóry i mierzono czas, po którym zostanie wchłonięta w skórę. Wykonano po 5 oznaczeń dla każdej próbki skóry, tzn. 15 prób dla każdego wariantu.

\section{Oznaczenie odporności na wysoką temperaturę na urządzeniu firmy SATRA (typ ASS)}

Z próbek skóry wycięto kwadraty o wymiarach $2 \mathrm{~cm} \times 2 \mathrm{~cm}$. Następnie próbki zważono i umieszczono stroną licową do dołu między pierścieniami urządzenia SATRA rozgrzanymi do temperatury ok. $300^{\circ} \mathrm{C}$ na metalowej łopatce. Po 5 minutach próbki były ważone i określono ubytek masy. Odporność na wysoką temperaturę w tym badaniu wykonano w warunkach „beztlenowych”. Próbka badana znajdowała się w zamkniętej przestrzeni między pierścieniami urządzenia. Wykonano 3 oznaczenia dla każdej próbki skóry.

\section{Wet-blue leather retanning}

Weighed skin samples were placed in water baths containing $10 \%$ of various mixtures in six cylindrical glass vessels (Wacker-type device). The volume of water used was $100 \%$ of the leather mass. The vessels with contents were rotated (time $-4 \mathrm{~h}$, temperature - approx. $50^{\circ} \mathrm{C}$ ). 30 minutes before the end of this retanning bath, a formic acid solution was added ( $1 \%$ of pure formic acid per leather mass, acid concentration of $10 \%$ ). Next, the leather was softened mechanically (through stretching) and dried under conditions appropriate to reach a humidity of $10-15 \%$. The degree of melamine and silica introduction into the leather was evaluated directly by determining the dry mass of bath before and after retanning (a result of approx. 90\% was indicated - for all the variants). This was also confirmed by the organoleptic evaluation of the used-up (post-process) baths.

\section{Determining shrinkage temperature}

Shrinkage temperature was determined in accordance with PN-EN ISO 3380:2015-11 [24]. 3 determinations for each sample were made, giving 9 in total for each variant.

\section{Softness determination}

Softness was determined in accordance with PN-EN ISO 17235:2002 [25]. 5 determinations for each sample were made, giving 159 in total for each variant.

\section{Water drop absoption test}

a drop of distilled water was applied onto a leather sample using a pipette, and the time after which it was absorbed into the leather was measured. 5 determinations for each sample were made, giving 15 in total for each variant.

\section{Determining resistance to high temperature using} a SATRA device (ASS type)

$2 \mathrm{~cm} \times 2 \mathrm{~cm}$ squares were cut out from leather samples. Next, the samples were weighed, on a metal spatula, grain-side down between the rings of the SATRA device heated up to approx. $300^{\circ} \mathrm{C}$. After 5 minutes the samples were weighed and the decrease in mass was determined. Resistance to high temperature was tested in "anearobic" conditions. The tested sample was located in the closed space between the rings of the device. 3 determinations for each sample were made. 


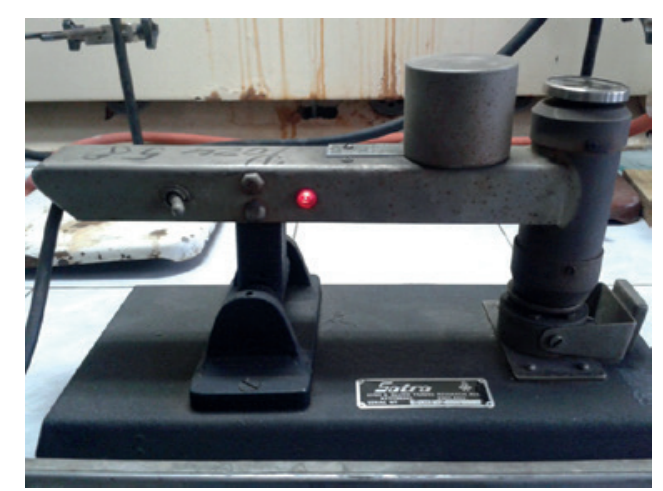

Rycina 2. SATRA - przyrząd do badania odporności na wysoką temperaturę

Figure 2. SATRA - a device for testing resistance to high temperatures

Źródło: Opracowanie własne.

Source: Own elaboration.

Pomiar odporności na palność - prostokątnej próbki

Ze skóry wycięto prostokąty o wymiarach $2,5 \mathrm{~cm} \times 10 \mathrm{~cm}$ i po ich dwóch stronach nacięto otwory wg ryc. 3a, które służą do zamocowania próbki drutem metalowym. Odpowiednie wyprofilowanie konstrukcji drutu stalowego mocującego próbki skóry pozwalało na obiektywną ocenę stopnia przepalenia skóry, ponieważ próbka była rozciągana i czas palenia próbki był liczony do momentu jej rozerwania. Na odpowiedniej wysokości zamocowano próbkę (licem do góry - ponieważ próbki skór były w stanie crust, wytrzymałość na palenie powinna być mniejsza od strony mizdry) równolegle do podłoża. Pod próbką umieszczono palący się palnik spirytusowy (ryc. 3b i 3c). Następnie mierzono czas, po którym próbka ulegnie przepaleniu (zerwaniu). Zastosowana metoda w znacznie większym stopniu uwzględnia rzeczywiste warunki występujące podczas palenia się obuwia czy odzieży ochronnej skórzanej na człowieku. Żaden ze znanych i powszechnie stosowanych sposobów oznaczania palności nie jest tak zbieżny z warunkami rzeczywistymi. Wykonano 3 oznaczenia dla każdej próbki skóry.

a)

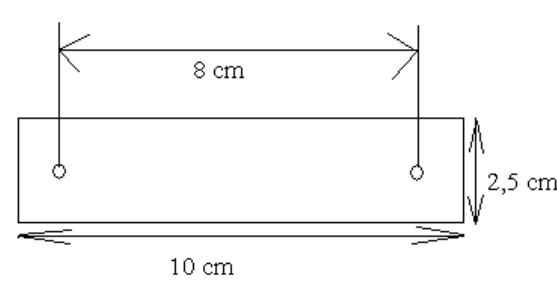

b)

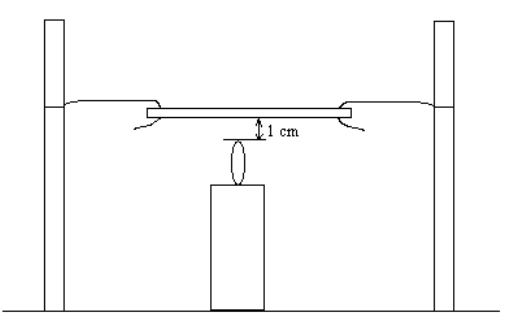

Flame resistance measurement - rectangular sample

$2.5 \mathrm{~cm} \times 10 \mathrm{~cm}$ rectangles were cut out from leather, and incisions were made on two sides, as demonstrated in Fig. 3a, to secure the sample with a metal wire. The proper profiling of the structure of the steel wire holding the leather samples made it possible to objectively assess the degree of burn. This is because the sample was stretched and the burning time of the sample was measured until it tore apart. The sample was located at the correct height (grain-side up - since the samples were samples of crust leather, flame resistance should be lower on the flesh side), parallel to the ground. A flaming alcohol burner was positioned under the sample (Fig. 3b and 3c). Time until burning through (tearing apart) was measured. The applied method to a greater degree takes into account the real conditions observed when leather protective footwear or clothing is worn and is burning. None of the known and commonly used flammability testing methods is so aligned with the real conditions. 3 determinations for each sample were made. c)

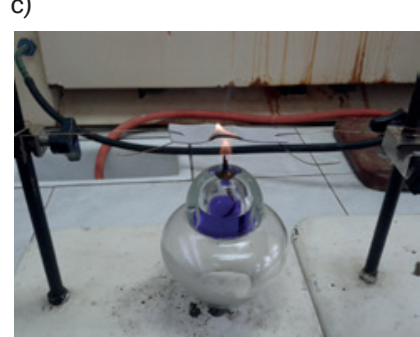

Rycina 3. Stanowisko do badań palności próbki skóry ( prostokąt)

Figure 3. The stand for testing the flammability of sample leather (a rectangular)

Źródło: Opracowanie własne.

Source: Own elaboration.

\section{Pomiar odporności na palność - okrągłej próbki}

W specjalnej metalowej kształtce umieszczono próbkę skóry o średnicy ok. $60 \mathrm{~mm}$ i szczelnie zakręcono (licem do góry). Następnie zamocowano ją w łapie stojaka nad palnikiem tak, aby wierzchołek płomienia znajdował się na środku pod kształtką. Mierzono czas do momentu przepalenia otworu w próbce. W tym przypadku skóra była zamocowana i przepalenie następowało
Flame resistance measurement - circular sample

A sample of leather with a diameter of approx. $60 \mathrm{~mm}$ was placed in a special metal profile and closed tightly (grain-side up). Next, it was placed on a rack arm above the burner, and made sure that the tip of the flame was centred below the profile. The time until a hole was burned through in the sample was measured. In this case, the leather was secured, and no external 
bez udziału sił zewnętrznych. Jednocześnie skóra była dodatkowo ogrzewana przez metalowy element mocujący. Wykonano 3 oznaczenia dla każdej próbki skóry.

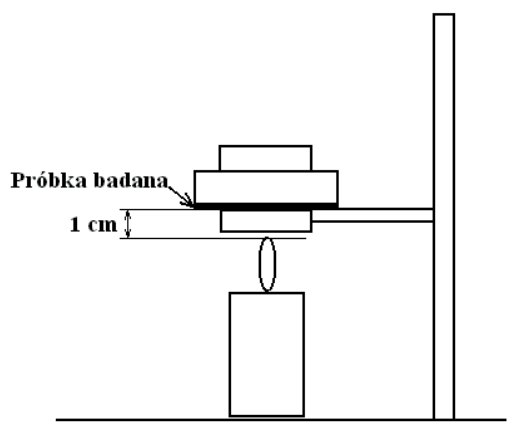

[Próbka badana - tested sample]

Rycina 4. Stanowisko do badania palności skóry (koło)

Figure 4. The stand for testing the flammability of leather (circle)

Źródło: Opracowanie własne.

Source: Own elaboration.

Pomiar przepuszczalności pary wodnej

Zgodnie z patentem nr 210759 [26] wykonano 3 oznaczenia dla każdej próbki skóry, tzn. 9 prób dla każdego wariantu.

\section{Metoda Kleemana}

Metodę Kleemana wykorzystano przy wyborze optymalnych parametrów otrzymywania skóry o właściwościach niepalnych $[27,28]$. Powala ona uzyskać graficznie kompromisowe optimum właściwości przy minimalnej ilości eksperymentów (6). Obszarem badania tej metody jest prostokąt zawierający punkty na powierzchni kulistej, które obrazuje wykres funkcji $Z=(x ; y)$ w przestrzeni trójwymiarowej. Przedstawia on zależność między właściwościami i zmiennymi czynnikami. forces contributed to the burning. At the same time, the leather was heated up by the metal fastener. 3 determinations for each sample were made.

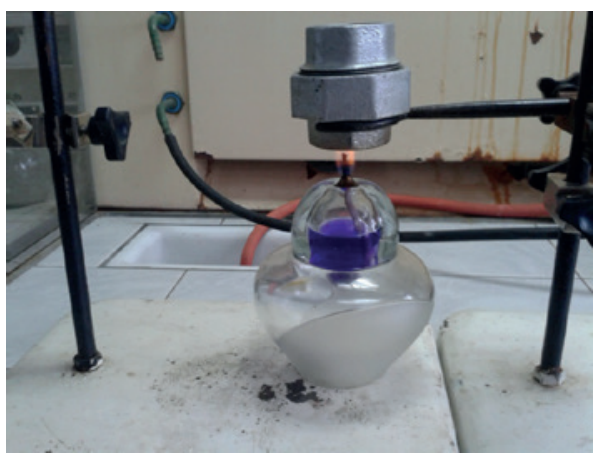

Water vapour permeability testing

In accordance with patent 210759 [26] 3 determinations for each sample were made, giving 9 in total for each variant.

\section{Kleeman's method}

Kleeman's method was applied when selecting the optimal parameters for leather with non-combustible properties [27, 28]. This method makes it possible to obtain a compromise optimum of properties with the least number of experiments needed (6). The test area is a rectangle containing points on a spherical surface, which is illustrated by a graph of the function $Z=(x ; y)$ in a three-dimensional space. It presents the correlation between properties and variable factors.

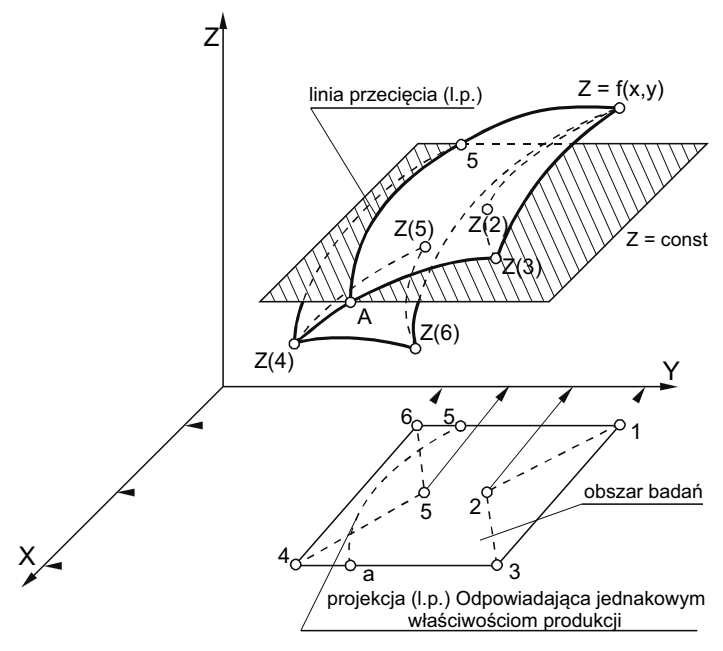

[linia przecięcia (I.p.) - line of intersection (l.i.)

Obszar badań - Test area

Projekcja (I.p.)... - projection (I.i.) reflecting identical production properties]

Rycina 5. Schemat planowania eksperymentu (według Kleemana)

Figure 5. A schematic showing experiment planning (according to Kleeman)

Źródło: Opracowanie własne.

Source: Own elaboration. 
Metoda ta powala uzyskać kompromisowe optimum parametrów procesu przy założonych właściwościach produktu końcowego, realizując minimalną liczbę eksperymentów technologicznych.
This method facilitates a compromise optimum of process parameters taking into account the assumed properties of the finished product, with the minimum number of engineering experiments being performed.

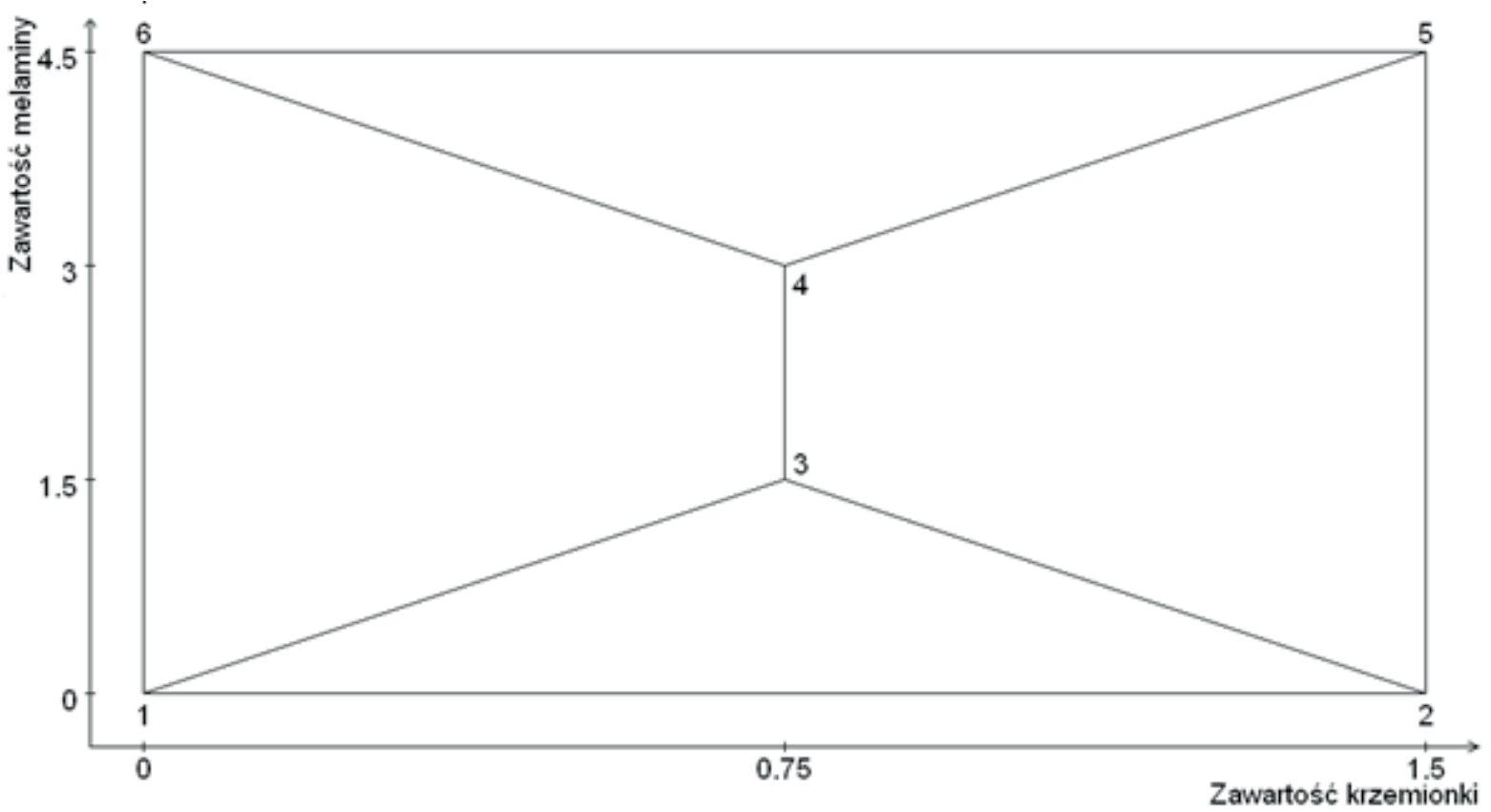

[Zawartość melaminy - Melamine content

Zawartość krzemionki - Silica content]

Rycina 6. Dobór parametrów eksperymentów dogarbowania z dodatkiem melaminy i krzemionki (wg metody Kleemana)

Figure 6. Selection of retanning experiment parameters with added melamine and silica (according to the Kleeman's method)

Źródło: Opracowanie własne.

Source: Own elaboration.

\section{Rezultaty badań. Dobór składu emulsji na bazie żywicy akrylowej}

W celu realizacji tematu badań do emulsji żywicy akrylowej wprowadzono dodatki mogące podwyższyć palność skóry. Skład kompozycji dogarbowujących został opracowany na podstawie wstępnych badań stabilności ich $10 \%$ dyspersji wodnych. Stabilność wodnych dyspersji kompozycji dogarbowujących jest jednym z najważniejszych parametrów gwarantujących wnikanie składników kompozycji w strukturę skóry. W poszczególnych wariantach od 1 do 6 użyto próbek skór według ryc. 1. Do optymalizacji użyto metody Kleemana, polegającej na zmianie dwóch parametrów wyjściowych (zawartość krzemionki i zawartość melaminy) według proporcji podanych na ryc. 6 . Na podstawie sześciu eksperymentów otrzymujemy zależności użytych ilości krzemionki i melaminy na poszczególne badane właściwościach skór.

\section{Test results. Selection of the composition of the acrylic-resin-based emulsion}

In order to pursue the subject of the research, additives were introduced to acrylic resin to improve the flame resistance of leather. The compositions of retanning mixtures were developed on the basis of preliminary stability tests of their $10 \%$ water dispersions. The stability of the water dispersions of retanning mixtures is one of the most important parameters which guarantee the penetration of compound constituents into the leather structure. In variants 1 to 6 the leather samples were used in accordance with Figure 1. Kleeman's method was used for optimisation. It consisted of changing the initial parameters (silica content and melamine content) according to the proportions specified in Figure 6. Based on the six experiments it was possible to determine the correlations between the amount of silica and melamine and the tested individual properties of leather. 
Tabela 5. Skład kompozycji - plan sześciu eksperymentów wg Kleemana

Table 5. The composition of the mixture - the plan for six experiments (according to Kleeman's method)

\begin{tabular}{|c|c|c|c|c|c|c|c|c|c|c|c|}
\hline \multirow{3}{*}{$\begin{array}{c}\text { Wariant/ } \\
\text { Variant }\end{array}$} & \multicolumn{10}{|c|}{ Składniki kompozycji/Ingredients of the mixture } & \multirow{3}{*}{$\Sigma[g]$} \\
\hline & \multicolumn{2}{|c|}{ Rokryl GA16 } & \multicolumn{2}{|c|}{$\begin{array}{l}\text { Melamina/ } \\
\text { Melamine }\end{array}$} & \multicolumn{2}{|c|}{$\begin{array}{c}\text { Krzemionka HDK N20/ } \\
\text { Silica HDK N20 }\end{array}$} & \multicolumn{2}{|c|}{$\begin{array}{l}\text { Metyloceluloza/ } \\
\text { Methylcellulose }\end{array}$} & \multicolumn{2}{|c|}{$\begin{array}{l}\text { Emulgator/ } \\
\text { Emulsifier }\end{array}$} & \\
\hline & [g] & {$[\%]$} & [g] & [\%] & [g] & [\%] & [g] & [\%] & [g] & [\%] & \\
\hline 0 & 0 & 0 & 0 & 0 & 0 & 0 & 0 & 0 & 0 & 0 & 0 \\
\hline 1 & 297,00 & 98,0 & 0 & 0 & 0 & 0 & \multirow{6}{*}{3,0} & \multirow{6}{*}{1} & \multirow{6}{*}{3,0} & \multirow{6}{*}{1} & \multirow{6}{*}{303} \\
\hline 2 & 295,50 & 97,5 & 0 & 0 & 1,50 & 0,5 & & & & & \\
\hline 3 & 294,75 & 97,3 & 1,5 & 0,5 & 0,75 & 0,2 & & & & & \\
\hline 4 & 293,25 & 96,8 & 3,0 & 1 & 0,75 & 0,2 & & & & & \\
\hline 5 & 291,00 & 96,0 & 4,5 & 1,5 & 1,50 & 0,5 & & & & & \\
\hline 6 & 292,50 & 96,5 & 4,5 & 1,5 & 0 & 0 & & & & & \\
\hline
\end{tabular}

Źródło: Opracownaie własne.

Source: Own elaboration

W przypadku wariantu 0 próbka była próbką odniesienia.

\section{Zestawienie wyników}

W tabeli 6 przedstawiono zestawienie średnich wyników badań właściwości skór. Próbki skór odpowiadają wariantom podanym $w$ tabeli 6 zgodnie $z$ danymi z ryc. 1 .
In the case of variant 0 the sample was the reference sample.

\section{Breakdown of results}

Table 6 presents a breakdown of mean results of studies testing leather properties. The leather samples correspond to the variants indicated in Table 6 in line with the data presented in Figure 1.

Tabela 6. Zestawienie wyników badań właściwości skór

Table 6. A breakdown of results concerning the properties of leather

Wyniki badań próbek skór/ Properties of leather

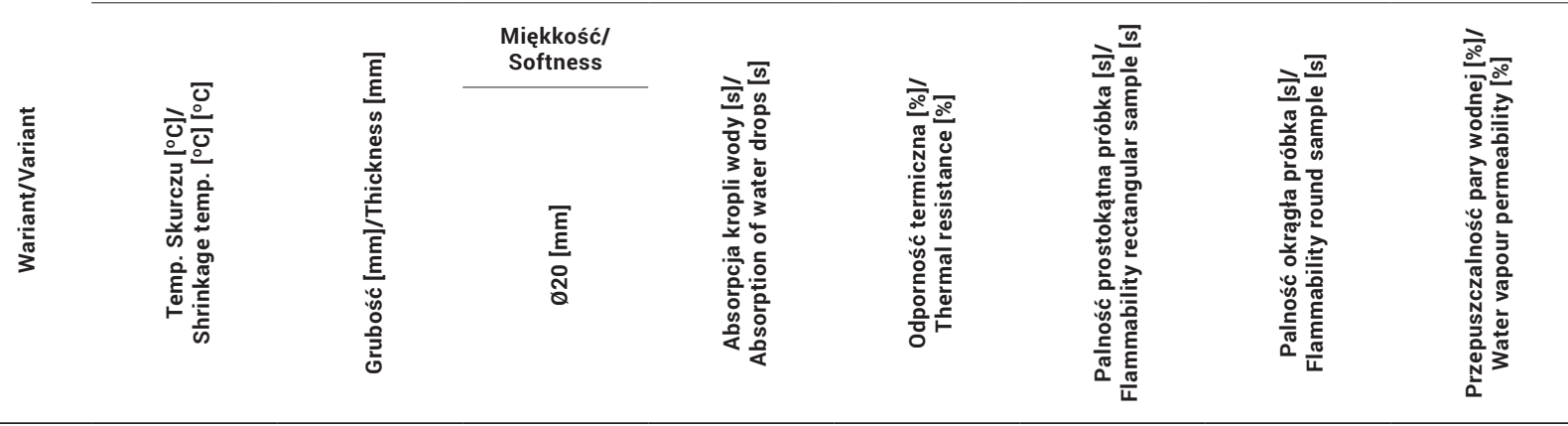

\begin{tabular}{|c|c|c|c|c|c|c|c|c|}
\hline 0 & 108 & 1,6 & 2,3 & 62 & 37 & 68 & 71 & 86 \\
\hline 1 & 111 & 1,9 & 2,4 & 115 & 41 & 76 & 127 & 73 \\
\hline 2 & 111 & 2,0 & 2,3 & 53 & 40 & 74 & 122 & 75 \\
\hline 3 & 111 & 2,0 & 2,2 & 70 & 40 & 85 & 143 & 75 \\
\hline 4 & 112 & 2,0 & 2,6 & 36 & 38 & 68 & 150 & 75 \\
\hline 5 & 110 & 2,0 & 2,0 & 30 & 39 & 70 & 153 & 76 \\
\hline 6 & 112 & 2,0 & 2,3 & 26 & 38 & 73 & 137 & 77 \\
\hline
\end{tabular}

Źródło: Opracownaie własne.

Source: Own elaboration.

\section{Optymalizacja wyników badań}

Na rycinach 7-13 podane zawartości użytych krzemionki i melaminy odnoszą się do ilości [g] podanych w tabeli 6 .

\section{Study results optimisation}

In Figures $7-13$ the indicated content of silica and melamine relate to the amounts $[\mathrm{g}]$ specified in Table 6. 


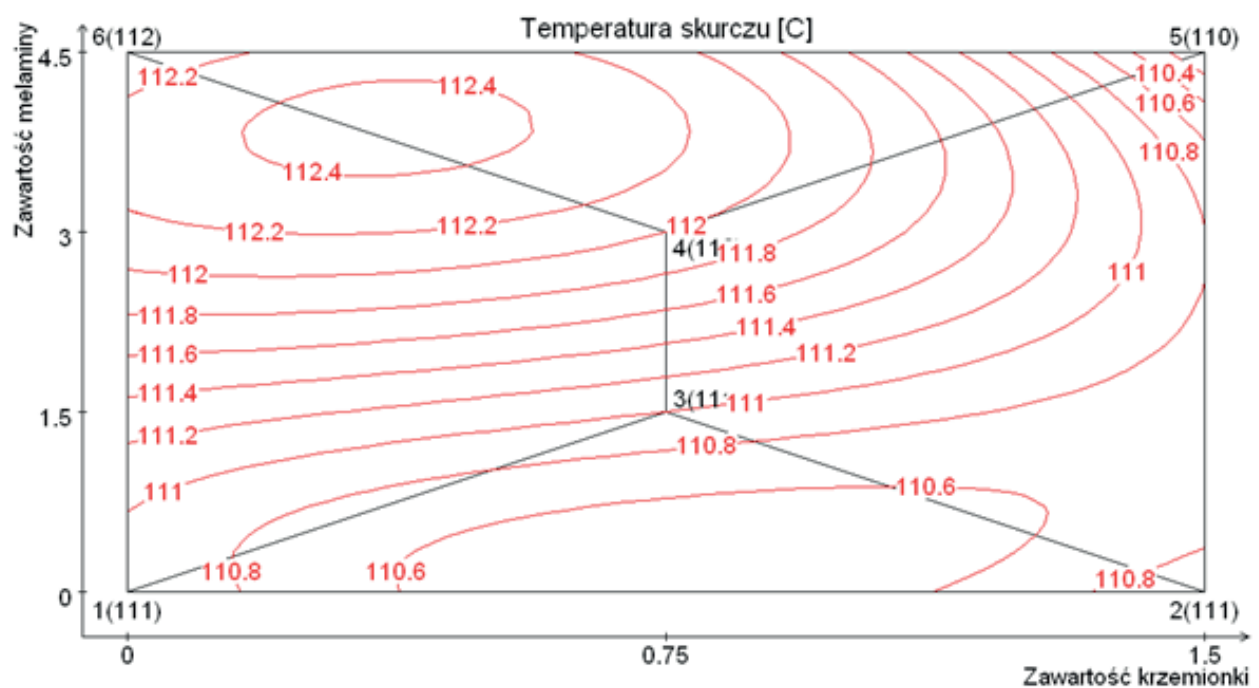

[Temperatura skurczu - Shrinkage temperature]

Rycina 7. Wpływ składu kompozycji dogarbowującej na temperaturę skurczu skóry

Figure 7. The effect of the composition retanning for temperature shrinkage of the leather

Źródło: Opracowanie własne.

Source: Own elaboration.

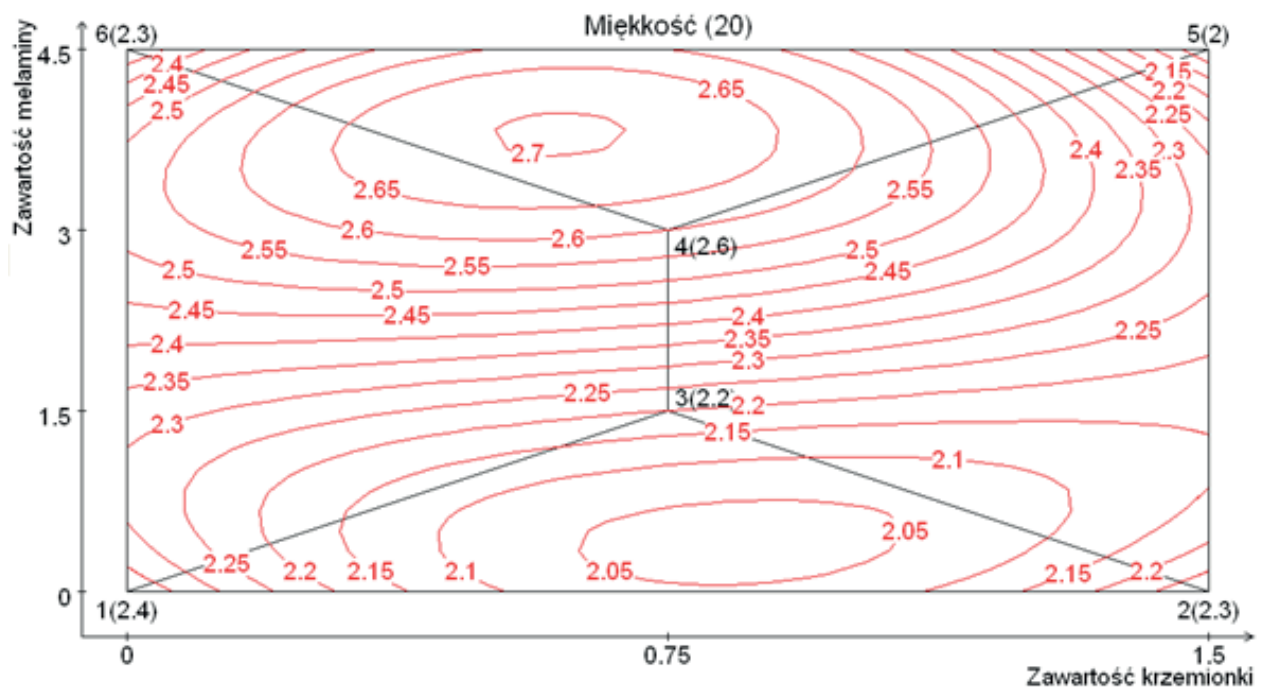

[Miękkość - Softness]

Rycina 8. Wpływ składu kompozycji dogarbowującej na miękkość skóry ( Ø20 mm)

Figure 8. Effect of the composition of the retanning mixture on leather softness $(\emptyset 20 \mathrm{~mm})$

Źródło: Opracowanie własne.

Source: Own elaboration.

Większa ilość dodawanej melaminy powoduje niewielki wzrost temperatury skurczu. Krzemionka praktycznie nie wpływa na odporność hydrotermiczną.

Zdecydowany wzrost ilości zastosowanej melaminy daje większą miękkość skóry do granicy 2,7. Ilość krzemionki w kąpieli dogarbowującej praktycznie nie wpływa na miękkość skór.
A greater amount of melamine added results in a small increase in shrinkage temperature. Silica has virtually no effect on hydrothermal resistance.

A significant increase in the amount of melamine applied translates into greater leather softness up to 2.7. The amount of silica in the retanning bath has virtually no effect on leather softness. 


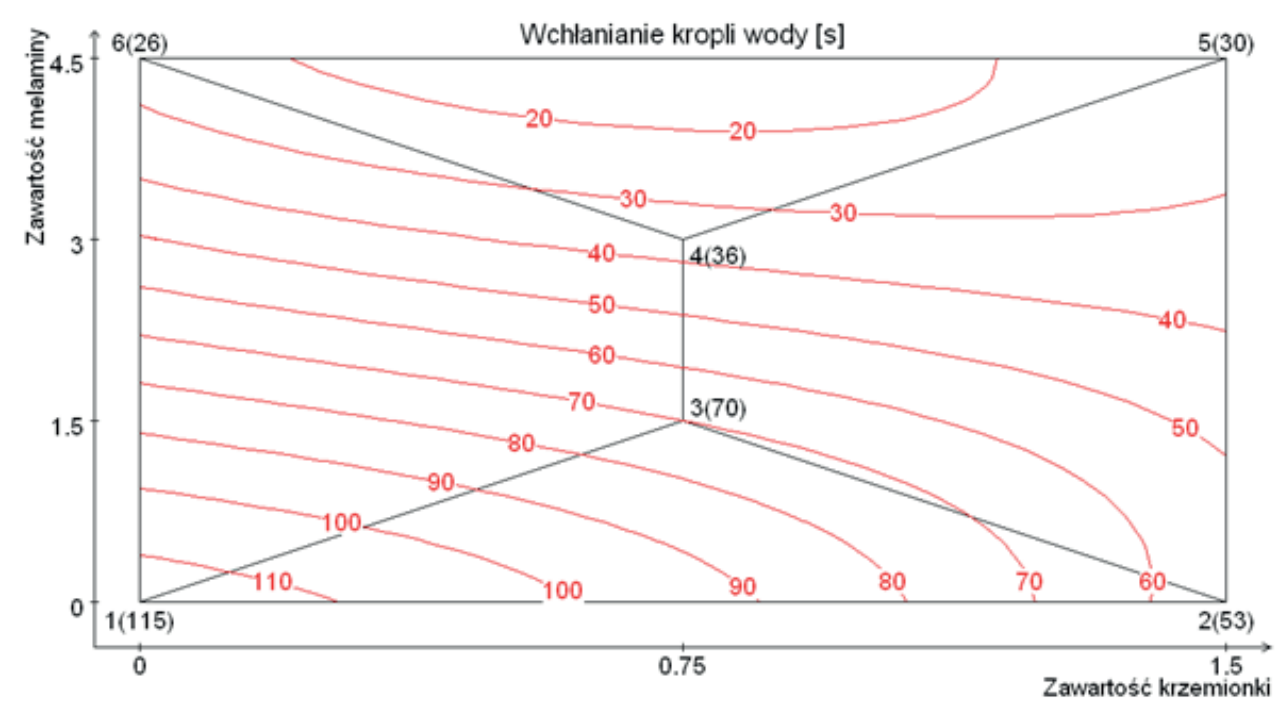

[Wchłanianie kropli wody - Absorption of a drop of water]

Rycina 9. Wpływ składu kompozycji dogarbowującej na wchłanianie kropli wody przez skórę

Figure 9. Effect of the composition of the retanning mixture on the absorption of a drop of water into leather Źródło: Opracowanie własne.

Source: Own elaboration.

Ze wzrostem ilości zastosowanej melaminy i krzemionki skraca się czas wchłaniania wody przez skórę, przy czym oddziaływanie krzemionki jest tutaj silniejsze.

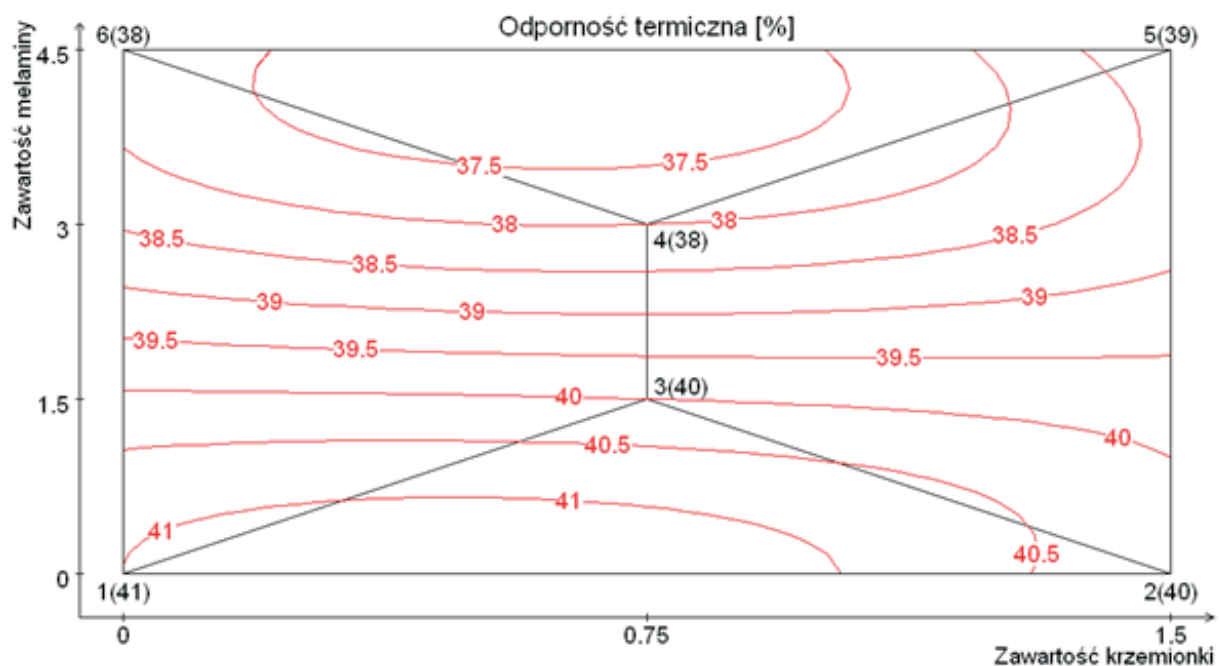

[Odporność termiczna - Temperature resistance]

Rycina 10. Wpływ składu kompozycji dogarbowującej na odporność na wysoką temperaturę skóry (urządzenie Satra)

Figure 10. Effect of the composition of the retanning mixture on high temperature resistance of leather (device Satra)

Źródło: Opracowanie własne.

Source: Own elaboration.

W danym badaniu wraz ze wzrostem ilości zastosowanej melaminy maleje ubytek masy. To badanie ma specyficzny charakter, ponieważ próbka skóry jest odizolowana od powietrza. Beztlenowy rozkład jest związany z obecnością w skórze żywicy akrylowej , metylocelulozy i emulgatora, których sumaryczna zawartość jest mniejsza w przypadku wariantów o wyższej zawartości melaminy i krzemionki.
The greater the amount of melamine and silica, the shorter the water absorption time. It should be also noted that silica has a stronger effect in this regard. 


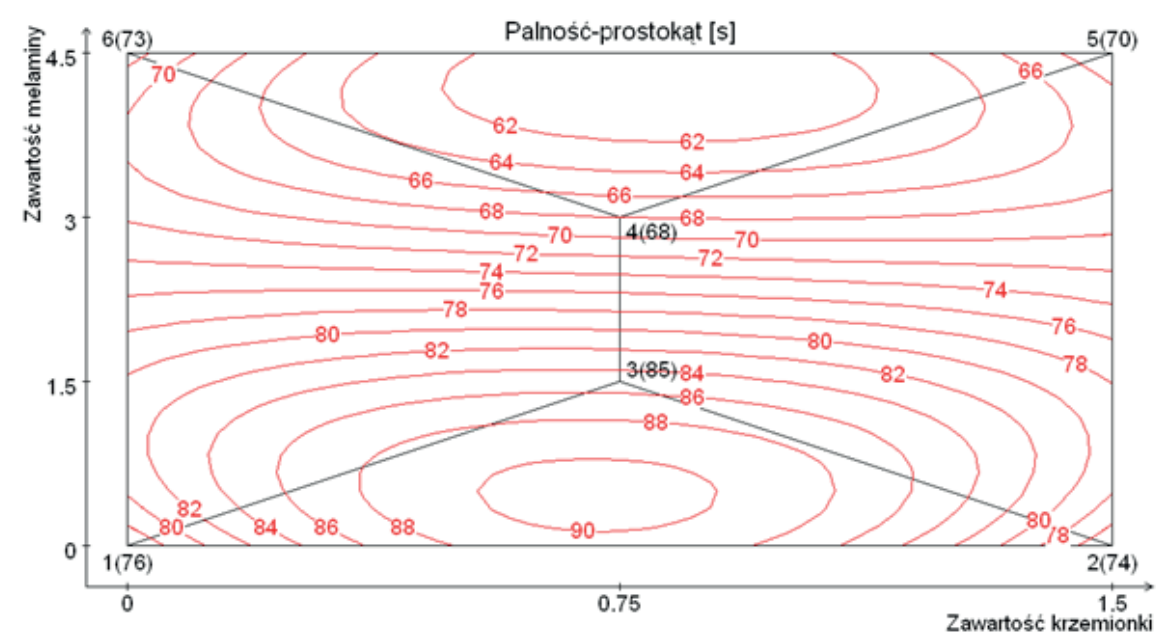

[Palność-prostokąt - Flammability (rectangle)]

Rycina 11. Wpływ składu kompozycji dogarbowującej na odporność na palność skóry (prostokąt)

Figure 11. Effect of the composition of the retanning mixture on the flame resistance of the leather (rectangle)

Źródło: Opracowanie własne.

Source: Own elaboration.

Istnieje optimum ilości krzemionki (ok. 0,75 g tzn. 0,25\%) i melaminy (ok. 0,5 g tzn. 0,17\%) w kompozycji dogarbowującej, która sprzyja maksymalnej odporności w warunkach prowadzonych badań. To badanie odporności na palność ma charakter specyficzny, związany z występowaniem siły rozrywającej podczas badania. Stąd wyniki badań wskazują, że zwiększenie ilości zarówno użytej melaminy (w większym stopniu), jak i krzemionki (w mniejszym stopniu) obniża odporność na palenie. W rzeczywistości może to być jednak związane nie ze zmniejszeniem się odporności na palność, lecz ze zmianą wytrzymałości skóry na rozciąganie (zależnej także od usytuowania próbki skóry w strukturze topograficznej skóry) w warunkach wysokiej temperatury (moment rozerwania się próbki jest uznawany za kluczowy dla metody).
There were optimal amounts of silica (approx. $0.75 \mathrm{~g}$ or $0.25 \%$ ) and melamine (approx. $0.5 \mathrm{~g}$ or $0.17 \%$ ) in the retanning mixtures, which were conducive to reaching maximum resistance in the test conditions. This flame resistance test was specific, and was associated with the presence of the tearing force during the test. Therefore, the test results indicate that increasing the amount of melamine (to a greater extent) and silica (to a smaller extent) decreases flame resistance. This, however, may not be related to a decrease in flame resistance, but to a change in the tensile strength of leather (which also depends on the location of the leather sample in the topographic structure of the hide) in high-temperature conditions (the moment of the sample becoming torn apart is crucial for this method).

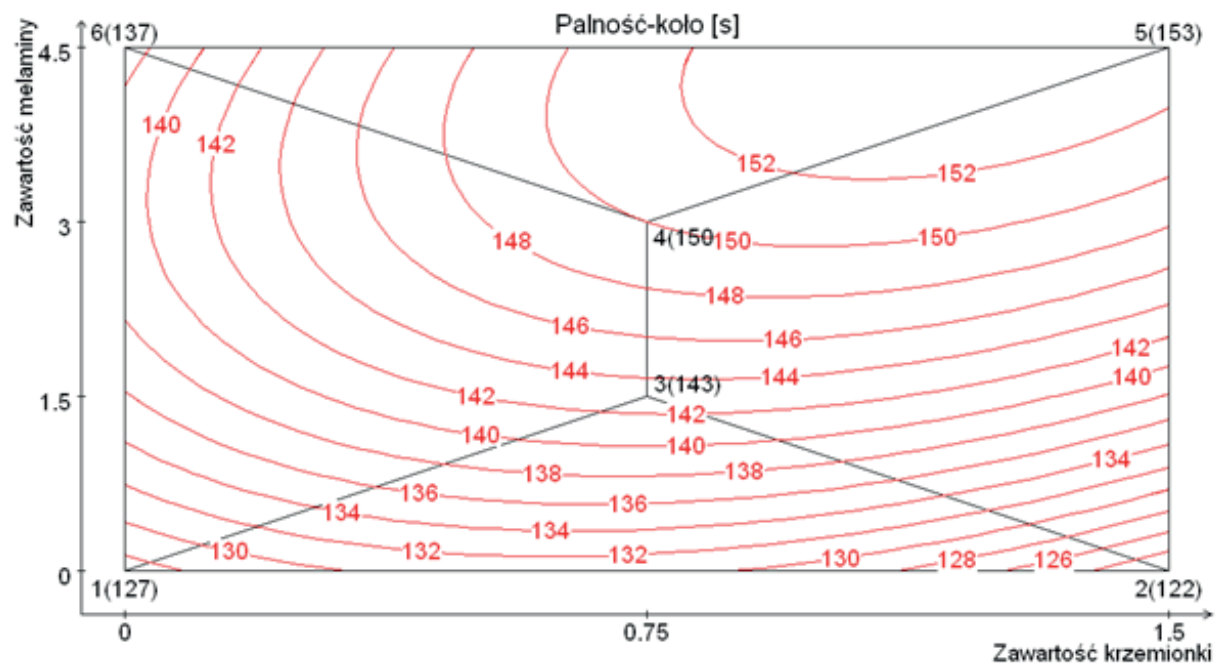

[Palność - koło - Flammability - circle]

Rycina 12. Wpływ składu kompozycji dogarbowującej na odporność na palność skóry (koło)

Figure 12. Effect of the composition of the retanning mixture on the flame resistance of leather (circle)

Źródło: Opracowanie własne.

Source: Own elaboration. 
W metodzie z pierścieniem większa ilość melaminy w kąpieli dogarbowującej równa się zdecydowanemu wzrostowi odporności skóry na przepalenie. W tym przypadku wyniki badań potwierdzają pozytywny wpływ stosowanych dodatków (przede wszystkim melaminy) na wzrost odporności na palenie. Widoczny efekt synergiczny dodatku krzemionki po przekroczeniu stężenia dodatku melaminy ok. 0,5\% (1,5 g).
As regards the ring method, a greater amount of melamine in the retanning batch equals a substantial increase in flame resistance of leather. In this case the results of the tests corroborate the positive impact of the additives used (in particular of melamine) on improved flame resistance. The synergistic effect of adding silica was observed after exceeding approx. $0.5 \%$ $(1.5 \mathrm{~g})$ concentration of melamine.

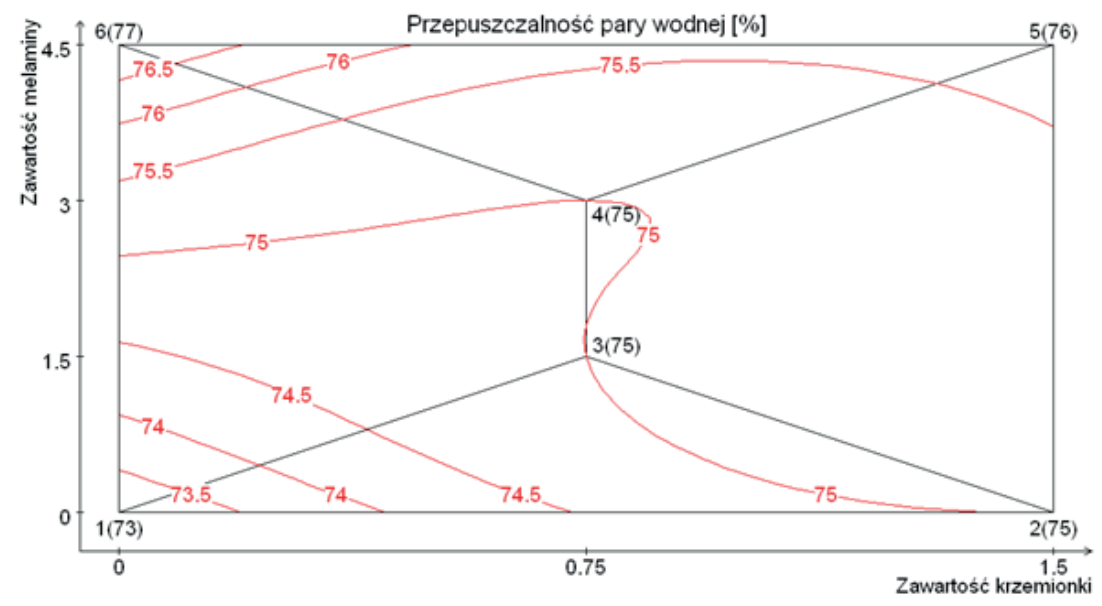

[Przepuszczalność pary wodnej - Water vapour permeability]

Rycina 13. Wpływ składu kompozycji dogarbowującej na przepuszczalność pary wodnej skóry

Figure 13. Effect of the composition of the retanning mixture on the water vapour permeability of leather

Źródło: Opracowanie własne.

Source: Own elaboration.

Wprowadzenie krzemionki i melaminy powoduje praktycznie nieznaczący spadek przepuszczalności pary wodnej.
The introduction of silica and melamine results in an insignificant decrease in water vapour permeability.

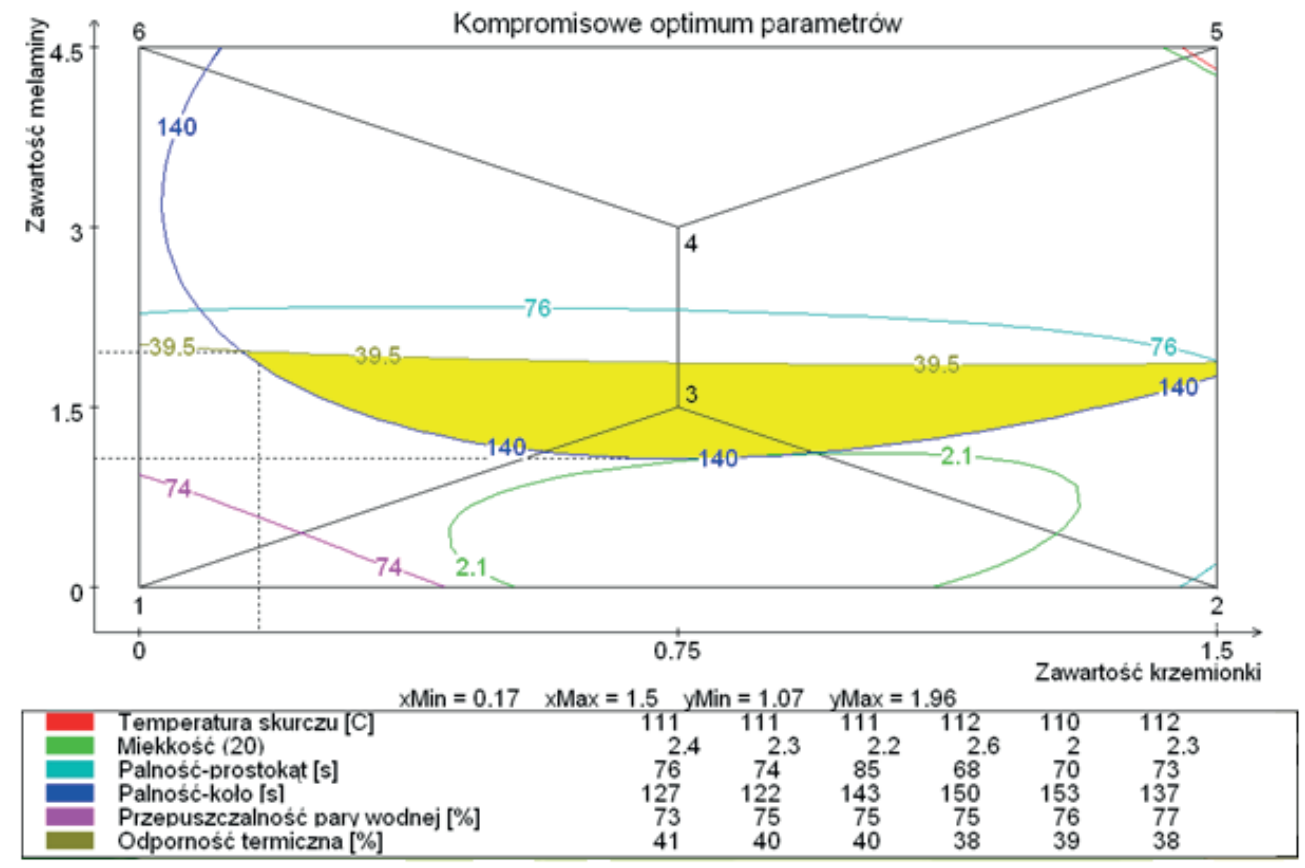

[Kompromisowe optimum paramterów - Compromise optimum of parameters]

Rycina 14. Kompromisowe optimum składu kompozycji dogarbowującej

Figure 14. A compromise optimum of the composition of the retanning mixture

Źródło: Opracowanie własne.

Source: Own elaboration. 
Ocena procesu dogarbowania z dodatkiem środków uniepalniających (krzemionki i melaminy) może być dokonana poprzez pomiar wybranych parametrów skóry. Przy wyborze kompromisowego optimum założono wartości parametrów, które powinna mieć skóra, żeby mogła być uznana za pełnowartościowy materiał. Nie koncentrowano się przy tym wyłącznie na właściwościach związanych z palnością. Nie można przecież w obróbce zaproponować operacji, której efektem będą co prawda skóry o doskonałej odporności na palenie, ale o niskim wskaźniku komfortu użytkowania wyrobu (miękkość) czy właściwości higienicznych (przepuszczalność pary wodnej).

Przy założonych wartościach dotyczących właściwości skóry (temperatura skurczu $>110,5^{\circ} \mathrm{C}$; miękkość $>2,1$; palność-prostokąt > $76 \mathrm{~s}$; palność-koło > $140 \mathrm{~s}$; przepuszczalność pary wodnej > 74\%; odporność termiczna (Satra) > 39,5\%) kompromisowe optimum parametrów w warunkach przeprowadzonych badań wynosi (po przeliczeniu na stężenie w kompozycji dogarbowującej): dla krzemionki 0,06-0,5\% i melaminy $0,35-0,65 \%$.

\section{Wnioski}

Celem niniejszej pracy było określenie wpływu dogarbowania z dodatkiem krzemionki i melaminy na wybrane właściwości skóry, w tym na odporność na palenie.

Na podstawie przeprowadzonych badań stwierdzono, że:

1. Wzrost ilości użytej melaminy i krzemionki w składzie kompozycji powoduje wzrost odporności próbek skóry na przepalenie, przy czym dominujący jest wpływ melaminy. Potwierdzają to wyniki badań w przypadku zastosowania metody oznaczenia palności za pomocą pierścienia oraz przy użyciu przyrządu Satra.

2. Zastosowanie specjalnej metody oznaczenia palności próbki prostokątnej (próbka podczas badania jest rozciągana) nie potwierdza wyżej wymienionych zależności. Może to jednak wynikać z obniżenia wytrzymałości na rozciąganie w podwyższonej temperaturze, a nie z braku działania zmniejszającego palność przy zastosowanych dodatków melaminy i krzemionki. Zadaniem autorów metoda ta wymaga przeprowadzenia większej liczby oznaczeń (wykonano tylko 3).

3. Dogarbowanie zarówno z dodatkami (krzemionka i melamina), jak i bez dodatków minimalnie obniża przepuszczalność pary wodnej dla wszystkich badanych wariantów. Świadczy to o napełnianiu skór podczas dogarbowania.

4. Dogarbowanie prowadzi do wzrostu temperatury skurczu o max. $4^{\circ} \mathrm{C}$

5. Wyniki optymalizacji wskazują, że kompromisowe optimum przy założonych właściwościach skóry ma miejsce przy doborze składu kompozycji dogarbowującej na poziomie $0,06-0,5 \%$ dla krzemionki i $0,35-0,65 \%$ dla melaminy w warunkach przeprowadzonych badań.

6. Badania miały charakter wstępny i zostały wykonane w warunkach laboratoryjnych. Planuje się kontynuowanie badań w celu oznaczenia metodami instrumentalnymi ilości środków uniepalniających znajdujących się w skórze dla wybranej optymalnej kompozycji dogarbowującej.
The assessment of retanning with the addition of flame-retardant agents (silica and melamine) can be carried out by measuring the selected leather parameters. When selecting a compromise optimum, the parameters of leather to be regarded as a full-value material, were assumed. Our focus was not, however, solely on flammability-related properties. It would be ill-advised to recommend a procedure resulting in leather with excellent flame resistance but with low comfort of use (softness) or poor hygienic properties (water vapour permeability).

With the assumed values of leather properties (shrinkage temperature $>110.5^{\circ} \mathrm{C}$; softness $>2.1$; flammability-rectangle $>76 \mathrm{~s}$; flammability-circle $>140 \mathrm{~s}$; water vapour permeability $>74 \%$; thermal resistance (Satra) $>39,5 \%$ ) a compromise optimum of parameters in the test conditions (after converting into concentration in the retanning mixture) is: for silica $0.06-0.5 \%$ and melamine $0.35-0.65 \%$.

\section{Conclusions}

The objective of this paper was to determine the impact of retanning with added silica and melamine on the selected properties of leather, including flame resistance.

On the basis of the conducted tests it was determined that:

1. The increase in the amount of melamine and silica used in the composition of the mixture increases the resistance of leather samples to burnout. This has been corroborated by test results for the application of the flammability determination method utilising the ring and the Satra device

2. The application of a special method for determining the flammability of a rectangular sample (with the sample being stretched during the test) does not confirm the aforementioned relationships. This can, however, stem from a lower tensile strength at higher temperatures, and not from the lack of flame-retardant effect with added melamine and silica. In the authors' opinion, this method requires making more determinations (only 3 were performed).

3. Retanning which involves additives (silica and melamine) and no additives, results in minimally decreased water vapour permeability in all the tested variants. This proves the filling of leather during retanning.

4. Retanning leads to an increase in shrinkage temperature by max. $4^{\circ} \mathrm{C}$.

5. The results of the optimisation show that the compromise optimum given the assumed properties of the leather is obtained with the addition of melamine and silica in the retanning mixture at $0.06-0.5 \%$ for silica and $0.35-0.65 \%$ for melamine under the test conditions.

6. The tests were preliminary and were carried out in laboratory conditions. Further tests are planned in order to determine the amount of flame-retardant agents in leather in the selected optimal retanning mixture using instrumental methods. 


\section{Literatura/Literature}

[1] Bacardit A., Borràs M.D., Soler J., Herrero V., Jorge J., Olle L.L., Behavior of leather as a protective heat barrier and fire resistant material 2010, "Journal of the American Leather Chemists Association" 105(2), 51-61.

[2] Chen W., Liu C., Gong Y., Huang Z., Influence of tanning on the flammability of leather, "Journal of the Society of Leather Technologists and Chemists" 2007, 91(4), 159-161.

[3] Gong Y., Chen W., Chen J., Gu H., Influence of finishing on the flammability of leather, "Journal of the Society of Leather Technologists and Chemists" 2007, 91(5), 208-211.

[4] Huang Z., Lixin L.I., Chen W., Gui H., Influence of fatliquoring on flammability of leather, "Journal of the Society of Leather Technologists and Chemists" 2006. 90(4), 155-158.

[5] Huang Z., Li L., Wang Y., Lin Y., Chen W., Performance of flame retardants on leather, "Journal of the Society of Leather Technologists and Chemists", 2005, 89(6), 225-231.

[6] Xiuli Z., Yi C., Haojun F., Bi S., Waterborne polyurethane/O-MMT nanocomposites for flame retardant leather finishing, "Journal of the Society of Leather Technologists and Chemists" 2010, 94(2), 77-83.

[7] Yuanping Jiang, Jiaxun Li, BoLi, Hongyan Liu, Zhengjun Li, Lixin Li, Study on a novel multifunctional nanocomposite as flame retardant of leather, "Polymer Degradation and Stability" 2015, 115, 110-116.

[8] Liutao Y., Lixin L., Wuyong C., Lin L., Feng C., Thermal degradation kinetics and flame retardancy of hide treated with montmorillonite-amino resin nano-composite, "Journal of the Society of Leather Technologists and Chemists" 2010, 94(1), 9-14

[9] Mohamed O.A., Abdel-Mohdy F.A., Preparation of flame-retardant leather pretreated with pyrovatex $C P$, "Journal of Applied Polymer Science", 2006, 99(5), 2039-2043.

[10] Huijiao L., Jinwei Y., Ling X., (...), Minglian L., Lixin L., The synthesis and application of a high performance amino resin nanocomposite as leather flame retardant, "Journal of the Society of Leather Technologists and Chemists" 2012, 96(1), 5-10.

[11] Gaidau C., Popescu M., Piticescu M.R., Petica A., Anicai L., Iordache O., New smart materials for leather surface functionalisation (Conference Paper), XXXIII IULTCS Congress. 33rd International Union of Leather Technologists and Chemists, IULTCS Congress 2015; Novo Hamburgo; Brazil; 24-27 November 2015.

DR HAB. INŻ. KRZYSZTOF ŚMIECHOWSKI, PROF. UTH RAD. - reprezentuje nauki techniczne. Jest kierownikiem Zakładu Ekotechnologii Kolagenu i Tłuszczów na Wydziale Materiałoznawstwa Technologii i Wzornictwa Uniwersytetu Technologiczno-Humanistycznego im. K. Pułaskiego w Radomiu. Był dziekanem WMTiW, który zainicjował (wspólnie z rektorem UTH prof. Zbigniewem Łukasikiem) i otworzył kierunek studiów BHP. Obecnie jest kierownikiem zespołu odpowiedzialnego za kierunek studiów I stopnia BHP w WMTiW. Interesuje się tematyką polimerów naturalnych, szczególnie kolagenem. Realizuje działania badawcze w zakresie aplikacyjnym, technologicznym, materiałoznawczym, jak również obejmujące zagadnienia społecznej odpowiedzialności biznesu (CSR), ochrony środowiska i BHP.

INŻ. MARLENA STACHOWICZ - absolwentka Wydziału Materiałoznawstwa Technologii i Wzornictwa UTH w Radomiu na kierunku Technologia Chemiczna. Odbyła praktyki studenckie w Medicofarma S.A. Od 2017 roku studentka II stopnia na kierunku Technologia Chemiczna WMTIW UTH Radom.
[12] Kozlowski R.M., Muzyczek M., Walentowska J., Flame retardancy and protection against biodeterioration of natural fibers: State-of-Art and Future Prospects, "Polymer Green Flame Retardants", August $26,2014,801-836$.

[13] Kozłowski R.M., Muzyczek M., Improving the flame retardancy of natural fibres2012, "Handbook of Natural Fibres" 2, 30-62.

[14] Śmiechowski K., Beleska K., Zaliauskiene A., Coordinated approach to production of soft leather, "Journal of the Society of Leather Technologists \& Chemists (JSLTC)", Vol. 85 September-October 2005, 199-204.

[15] Maxwell C.A., Śmiechowski K., Żarłok J., Sionkowska A., Wess T.J., $X$-ray studies of a collagen material for leather production treated with chromium salt, JALCA, 2006, Vol. 101, 9-17.

[16] Lacy P.D.A., Flammability and heat resistance of natural and synthetic leathers, “Journal of "Coated Fabrics" 1976 5(3), 186-203.

[17] Yun-Xia Wei, Cong Deng, Ze-Yong Zhao, Yu-Zhong Wang, A novel organic-inorganic hybrid SiO2@DPP for the fire retardance of polycarbonate, "Polymer Degradation and Stability", 154 (2018), 177-185.

[18] Sanchez-Olivares G., Sanchez-Solis A., Calderas F., (...), Di Blasio A., Alongi J., Sodium montmorillonite effect on the morphology, thermal, flame retardant and mechanical properties of semi-finished leather, "Applied Clay Science" (2014), 102, 254-260.

[19] Prospekt Hurtowni Zaopatrzenia i zbytu RZEMIOSŁO Sp. z o.o. ul. Okulickiego 39, Radom.

[20] http://www.zapulawy.pl/402-melamina/lang/pl-PL/default.aspx [dostęp 27.02.2017].

[21] https://www.wacker.com [dostęp 27.02.2017].

[22] https://www.carlroth.com/downloads/sdb/pl/8/SDB_8421_PL_ PL.pdf [dostęp 10.01.2017].

[23] http://www.schillseilacher.de/en/markets-products/leather-chemicals/shoes.html [dostęp 27.02.2017].

[24] PN-EN ISO 3380:2005 Wyznaczanie temperatury skurczu.

[25] PN-EN ISO 17235:2002 Wyznaczanie miękkości.

[26] Śmiechowski K., Żarłok J., Skiba J., Sposób pomiaru przepuszczalności pary wodnej, Urząd Patentowy RP, Warszawa, Patent nr 210759, 29.02.2012.

[27] Kleeman W., Plaste und Kautschuk, 11, 1964, 723.

[28] Smirnow W., Jakubczyk K., OPTIKOMA program komputerowy, Politechnika Radomska, WMiTO 1997.

KRZYSZTOF ŚMIECHOWSKI PH.D. ENG. - professor at the Kazimierz Pulaski University of Technology and Humanities in Radom, represents technical sciences. He is the Chair of the Institute of Ecotechnology of Collagen and Fats at the Faculty of Materials Science and Design of the Kazimierz Pulaski University of Technology and Humanities in Radom. He served as Dean of the faculty and opened (together with the Vice-Chancellor of the Kazimierz Pulaski University of Technology and Humanities in Radom, Prof. Zbigniew Łukasik) the study major in OHS. At present he is the Head of the team responsible for the first-cycle studies in OHS at the Faculty of Materials Science and Design. His main interests include natural polymers, in particular collagen. He conducts research in the field of application, technology and materials science, including the issues of corporate social responsibility (CSR), environment protection and $\mathrm{OHS}$.

MARLENA STACHOWICZ ENG. - graduate of engineering studies in Chemical Technology at the Faculty of Materials Science and Design of the Kazimierz Pulaski University of Technology and Humanities in Radom. She completed practical placement at Medicofarma S.A. In 2017 she enrolled for second-cycle studies in Chemical Technology at the University of Technology and Humanities in Radom. 